\title{
Population Ageing and Price Level in Japan
}

\author{
Chee-Hong Law ${ }^{\mathrm{a}}$ \\ Universiti Sains Malaysia
}

\begin{abstract}
This paper estimates the cointegration between population ageing and inflation in Japan using the augmented autoregressive distributed lag model. The method provides a complete indication of cointegration and avoids false conclusions from a unit root test. Moreover, the transmission channel from ageing to the price level is investigated using the pairwise Granger causality. Based on the annual data from 1961 to 2018, a cointegration relationship is found, and the deflationary effect of ageing in Japan is confirmed. Additionally, the young dependency ratio inflates the price level in Japan. Lastly, ageing influences the price level via its impact on the labour supply.
\end{abstract}

Keywords: Ageing, Japan, augmented ARDL, transmission channels JEL classification: E31, J11

\section{Introduction}

Japan is experiencing a rapid ageing process. The percentage of citizens aged 65 and over is expected to reach $33.3 \%$ of its total population in 2036 (National Institute of Population and Social Security Research, 2017). Inevitably, the ageing society could affect socio-economic conditions in Japan. This paper focuses on the implication of ageing on inflation in Japan, whereby the ageing process has beleaguered the society and economy.

Sufficient papers have covered this issue in Japan. These attempts were conducted by simulating the effect of ageing on price level (e.g., Anderson et al., 2014; Fujita \& Fujiwara, 2016; Katagiri, 2012) or by estimating the actual data using econometric methods (e.g., Goh et al., 2020; Liu \& Westelius, 2016; Yoon et al., 2014). Anderson et al. (2014) reported a negative link between price and ageing via its impact on economic growth and land prices. The simulations of Fujita and Fujiwara (2016) and Katagiri (2012) also concurred with the deflationary effect of ageing. Liu and Westelius (2016) substantiated the same claim when examining the prefectures data; prefectures in Japan that experienced fast ageing could cause lower inflation. The time series analysis of Yoon et al. (2014) in Japan also showed that a higher old dependency ratio is associated with a lower inflation rate in Japan.

a Universiti Sains Malaysia, School of Social Sciences, Gelugor, Penang, Malaysia. Email: cheehong@usm.my

* The author would like to thank the anonymous referee and editor for comments to improve the draft. All errors remain mine.

This study was funded by the Fundamental Research Grant Scheme (FRGS), Ministry of Higher Education Malaysia, Phase 1/2019 (Grant No: FRGS/1/2019/SS08/USM/02/1). 
Since the simulation exercises rely on the rigid assumptions on the behaviour of the variables in the model, this paper adopts the econometric model to estimate the dynamics between inflation and ageing in Japan. Moreover, a review of the current literature shows that only a few empirical estimations use time series data to investigate this issue. This paper contributes to the current literature by deploying the augmented autoregressive distributed lag (ARDL) model to examine the evidence of cointegration more comprehensively. It extends the study of Goh et al. (2020), who used a method similar to this paper, but they fail to establish the impact of ageing on prices in the long run and the short run. There are two differences between this paper and that of Goh et al. (2020). First, this paper extends the data duration to cover more recent data. Second, this paper examines the transmission channels from ageing to price level. To do so, this paper includes more variables in the inflation equation; these variables are labour supply, property prices, and gross primary balance (fiscal balance). Omitting these variables could cause the omitted variable bias, causing bias and inconsistency in estimations. The transmission channel has been omitted by the time series analysis conducted by Yoon et al. (2014) and Liu and Westelius (2016). These authors only examined the long-run relationship and omitted the cointegration test and the short-run effect of ageing; in this paper, the omitted information from those papers is covered.

This paper is organised as follows: In Section 2, the theoretical discussion of how ageing could affect the price level is presented. Then, Sections 3 and 4 respectively cover the methodology and data in this paper. Section 5 provides the empirical results. Section 6 discusses the sensitivity analysis and the transmission channels that connect the influence of ageing on the price level. Conclusions are presented in Section 7.

\section{Theoretical Impact of Ageing on Price and Its Channels}

Current theoretical discussions have offered inconclusive views regarding the reaction of price to ageing. According to the life cycle hypothesis, net savers or the working population could reduce inflation by accumulating savings. However, the old-age population is in the dissaving stage. In other words, ageing will increase the propensity of consumption, which creates a greater aggregate demand, causing inflationary pressure on price. Moreover, Han (2019) elaborated on the positive relationships by presenting the wealth effect that links to consumption. Particularly, the old cohort will not reduce spending since they have more financial assets, causing upward pressure on the price. The other channel is the expectation channel; the old cohort continues to spend as they expect the government to implement an accommodative monetary and fiscal policy to sustain the wealth.

De Albuquerque et al. (2020) added that a fiscal deficit to cover the pension and healthcare expenditure leads to debt monetisation, which results in higher inflation. Katagiri et al. (2020) elaborated that ageing caused by a lower birth rate is inflationary as it will reduce the tax base and increase fiscal expenditure. Societe Generale (2016) suggested that ageing will be inflationary if it reduces labour force supply. It is because a lower labour supply will push up the production costs.

Conversely, the impact of ageing on price could be negative (De Albuquerque et al., 2020) because an ageing society could have a lower purchasing power. Han (2019) 
listed two channels to associate ageing with deflation. The first channel is the risk-taking channel, in which the old cohort is more conservative in consumption and running a business. The second is the credit channel, where the old cohort has more barriers to getting loans. Both channels will discourage consumption and investment. Eventually, the price level will move downward. Juselius and Takats (2016) and Liu and Westelius (2016) argued that ageing could be deflationary if it deteriorates the economic prospect and confidence. Aksoy et al. (2019) illustrated that ageing would affect the price via its impacts on innovation and investment. More specifically, the implication of ageing on a lower capital return rate has discouraged innovation activities. The slowdown in innovation also reduces investment. The secular stagnation hypothesis is also relevant in linking ageing and deflation. According to this hypothesis, deflation happens when ageing causes the demand to be lower and drag down the natural rate of interest and long-term growth rate (Liu and Westelius, 2016).

Moreover, a higher capital to labour ratio exists when ageing reduces labour supply and the capital return, which subsequently depresses the investment, gross domestic product (GDP), employment, and the price level (Bobeica et al., 2017). The other reason that ageing could lead to deflation is the political view. The government of an ageing society will prefer a low inflationary economy as the ageing voters will be negatively affected by inflation (De Albuquerque et al., 2020; Gajewski, 2015; Katagiri et al., 2020). Thus, a deflationary environment will give more political advantage to the government. The fiscal policy could be deflationary since Katagiri et al. (2020) suggested that ageing due to longer longevity prompts a government to increase income tax to win the vote of the older voters. Furthermore, Societe Generale (2016) argued that a fiscal deficit caused by ageing could lead to fiscal consolidation, reducing the price and output levels. Last but not least, the negative effect of ageing on property price highlighted by Levin et al. (2008) and Nishimura and Takats (2012) implies that the inflation performance will be undermined.

\section{Methodology}

The first step is to determine the integration of the variables by using the augmented Dickey-Fuller (ADF) test and the DF-GLS test. The lag length of the ADF and DF-GLS tests is decided using the Akaike Information Criterion (AIC) with a maximum lag of 10 . These tests are crucial to ensure no I(2) variable among the selected variables. Moreover, all unit root tests are conducted by including the trend component as the variables have generally shown patterns in the movement during the sample period.

Afterwards, the augmented ARDL method is applied to estimate the cointegration relationship. Pesaran et al. (2001) have proposed two tests to confirm the cointegration relationship in an equation, which are the overall F-test on the lagged variable $\left(\beta_{1}\right.$, $\beta_{2}$, and $\beta_{3}$ ) and the t-test on the lagged dependent variable $\left(\beta_{1}\right)$ in equation (1). Both tests require the dependent variable to be integrated at order one so that the interpretation is valid. Failing to meet this assumption could lead to degenerate cases where there is no cointegration. Since the unit root test could be subject to low test power, leading to a false conclusion, the augmented ARDL could reduce the dependence on the assumption that the dependent variable is an I(1) variable. Additionally, the augmented 
ARDL could avoid the degenerate lagged independent variable(s) case (Sam et al., 2019).

$$
\begin{aligned}
\Delta y_{t}= & \beta_{0}+\beta_{1} y_{t-1}+\beta_{2} x 1_{t-1}+\beta_{3} x 2_{t-1}+\beta_{4} \sum_{i=1}^{p-1} \Delta y 1_{t-i}+\beta_{5} \sum_{i=1}^{q-1} \Delta x 1_{t-i}+ \\
& \beta_{6} \sum_{i=1}^{r-1} \Delta x 2_{t-i}+\varepsilon_{t}
\end{aligned}
$$

where $y_{t}$ is the dependent variable (the natural logarithm of consumer price index); $x 1_{t}$ and $x 2_{t}$ are the independent variables (i.e., old dependency ratio, young dependency ratio, gross primary balance, the natural logarithm of real house price, the natural logarithm of GDP, the natural logarithm of broad money, and the natural logarithm of the labour force); $p, q$, and $r$ are the number lags decided by the Schwarz Information Criterion (SIC). Compared with the AIC, the SIC tends to prefer a model with fewer lags; a parsimonious model is preferable in a structural multivariate equation (Enders, 2015). The maximum lag for each variable is $4 .{ }^{1}$

The augmented ARDL, proposed by McNown et al. (2018), is based on the output from equation (1). On top of the two tests mentioned above, an additional F-test is applied on the lagged independent variables $\left(\beta_{2}\right.$ and $\left.\beta_{3}\right)$. Cointegration is confirmed if all tests reject the null hypothesis. If the null hypothesis of the third test is rejected, a degenerate lagged independent variable case is found, leading to the conclusion of no cointegration, even if the first two tests indicate otherwise. The null hypotheses and alternative hypotheses of (i) F-test on all lagged variables, (ii) t-test on the lagged dependent variable, and (iii) F-test on the lagged independent variable are presented below. Equally important, the critical values of the first hypothesis are based on Narayan (2005). This selection is appropriate because of the small sample size in this paper. The critical values to examine the second hypothesis are provided by Pesaran et al. (2001). Finally, Sam et al. (2019) produce the critical values to decide the validity of the last hypothesis.

(i) $H_{0}: \beta_{1}=\beta_{2}=\beta_{3}=0 ; H_{A}: \beta_{1}, \beta_{2}, \beta_{3} \neq 0$

(ii) $H_{0}: \beta_{1}=0 ; H_{A}: \beta_{1}<0$

(iii) $H_{0}: \beta_{2}=\beta_{3}=0 ; H_{A}: \beta_{2}, \beta_{3} \neq 0$

Once the cointegration is confirmed, an unrestricted error correction model (case 5: unrestricted constant and unrestricted trend) will be estimated to measure the short-run impact of ageing on inflation. Moreover, a long-run equation is produced as well. Finally, the pairwise Granger causality test is adopted to investigate transmission channels. The test involves estimating bivariate models with lags. The F-test is applied on the coefficient from the bivariate models; Granger causality is established if the null hypothesis of all coefficients equal to 0 is rejected. Since the impact from ageing to inflation could happen after lags, the lags to be included in the pairwise Granger causality are $3,6,9,12$ and 15 .

1 The author also tests for maximum lag lower than 4. However, serial correlation is detected when the model proposed by SIC is examined. 
Table 1. Data description

\begin{tabular}{|c|c|c|c|}
\hline Variable & Symbol & Source & Measurement \\
\hline Old dependency ratio & old_dep & $\begin{array}{l}\text { World Development } \\
\text { Indicators, World Bank }\end{array}$ & $\begin{array}{l}\text { Percentage of the } \\
\text { working-age population }\end{array}$ \\
\hline Young dependency ratio & young_dep & $\begin{array}{l}\text { World Development } \\
\text { Indicators, World Bank }\end{array}$ & $\begin{array}{l}\text { Percentage of the } \\
\text { working-age population }\end{array}$ \\
\hline Gross primary balance & $g p b \_g d p$ & IMF data mapper & Percentage of GDP \\
\hline Consumer price index & Icpi & $\begin{array}{l}\text { World Development } \\
\text { Indicators, World Bank }\end{array}$ & Index, base year 2000 \\
\hline Broad money & $\mathrm{lbm}$ & $\begin{array}{l}\text { World Development } \\
\text { Indicators, World Bank }\end{array}$ & Japanese Yen \\
\hline GDP & $\operatorname{lgdp}$ & $\begin{array}{l}\text { World Development } \\
\text { Indicators, World Bank }\end{array}$ & US dollar \\
\hline Real house price & Ihpr & OECD & Index, base year 2015 \\
\hline Labour force & $\| f$ & OECD & Total, thousand persons \\
\hline
\end{tabular}

\section{Data Descriptions}

Table 1 lists the symbols, sources and measurements for the variables in this paper. The annual data from 1960 to 2018 are compiled and estimated. Two demographic variables are examined here, i.e., old dependency ratio and young dependency ratio. The former indicates the ageing condition in Japan, whereas the latter is another potential important demographic factor behind the price change. The dependent variable of this paper is the consumer price index with the base year in 2000. The other factors that could affect the consumer price index are broad money, GDP, real house price index, labour force and primary balance. The former two variables are typically included in a price equation (e.g., Broniatowska, 2019; Juselius \& Takats, 2015). The remaining variables directly affect the price level or act as the transmission medium to link ageing to the price level, as mentioned in Section 2. Except for the old dependency ratio, young dependency ratio and primary balance, all variables are transformed into natural logarithm form before estimation.

\section{Empirical Results}

According to the unit root output in Table 2, consistency is found for most variables across the tests where these variables are I(1). The exceptions are old_dep, young_dep, Ihpr and Ibm. Old_dep is found to be I(2). As for young_dep, the results of ADF and DFGLS are inconsistent. Here the variable is considered as an I(2) variable. This conclusion for both demographic indicators is also in line with Goh et al. (2020). It is also clear that $\mathrm{Ibm}$ is an I(2) variable. Finally, Ihpr is considered as an I(1) variable in this case. Following Goh et al. (2020), the I(2) variables are transformed into the first differenced variables so that they can cointegrate with the other variables. 
Table 2. ADF and DF-GLS results

\begin{tabular}{|c|c|c|c|c|c|c|}
\hline \multirow{3}{*}{ Variable } & \multicolumn{3}{|c|}{ ADF } & \multicolumn{3}{|c|}{ DF-GLS } \\
\hline & \multicolumn{3}{|c|}{ Intercept and trend } & \multicolumn{3}{|c|}{ Intercept and trend } \\
\hline & Level & $\begin{array}{c}\text { First } \\
\text { differenced }\end{array}$ & $\begin{array}{c}\text { Second } \\
\text { differenced }\end{array}$ & Level & $\begin{array}{c}\text { First } \\
\text { differenced }\end{array}$ & $\begin{array}{c}\text { Second } \\
\text { differenced }\end{array}$ \\
\hline old_dep & $0.644(7)$ & $-1.717(6)$ & $-4.877(5)^{* * *}$ & $-2.739(7)$ & $-1.338(6)$ & $-3.771(5)^{* *}$ \\
\hline young_dep & $0.350(9)$ & $-2.866(10)$ & $-4.817(9) * * *$ & $-0.549(8)$ & $-3.524(10) * * *$ & \\
\hline$g p b \_g d p$ & $-2.415(1)$ & $-6.342(0) * * *$ & & $-2.474(1)$ & $-6.329(0)^{* * *}$ & \\
\hline Iсpi & $-1.563(1)$ & $-3.485(0) *$ & & $-1.368(3)$ & $-3.432(0)^{* *}$ & \\
\hline Ibm & $-1.034(2)$ & $-2.685(1)$ & $-11.036(0) * * *$ & $-1.216(2)$ & $-2.703(1)$ & $-10.622(0)^{* * *}$ \\
\hline Igdp_us & $-1.029(10)$ & $-3.396(9) *$ & & $-1.568(8)$ & $-5.954(0)^{* * *}$ & \\
\hline IIf & $-1.452(1)$ & $-3.447(0)^{*}$ & & $-1.274(1)$ & $-3.497(0)^{* *}$ & \\
\hline Ihpr & $-2.419(2)$ & $-4.215(1)^{* * *}$ & & $-1.171(3)$ & $-2.868(0)$ & $-2.632(2)$ \\
\hline
\end{tabular}

Note: The null hypothesis of the ADF and DF-GLS unit root test means that a unit root is found. Value in parentheses is the number of lags decided by AIC. $* * *, * *$ and * indicate significance level at $1 \%, 5 \%$ and $10 \%$, respectively.

Table 3. Results of diagnostic tests for ARDL

\begin{tabular}{lc}
\hline Diagnostic test & Results \\
\hline Jacque-Bera test & $0.093(0.954)$ \\
Bruesch-Godfrey Serial correlation test (2 lag) & $6.093(0.048)$ \\
Bruesch-Godfrey Serial correlation test (4 lag) & $8.039(0.090)$ \\
Breusch-Pagan-Godfrey heteroskedasticity test & $26.733(0.222)$ \\
Ramsey RESET F-statistic & $0.0066(0.9359)$ \\
\hline Note: The model specification of the ARDL is $(3,1,0,0,2,1,3,4)$. Value in parentheses is \\
$\quad$ the p-value of the test.
\end{tabular}

Based on the SIC, $\operatorname{ARDL}(3,1,0,0,2,1,3,4)$ is chosen as a model that has the lowest SIC value. Table 3 lists the output of the main performance indicators of that model, namely, the Jacque-Bera normality test, Bruesch-Godfrey Serial correlation test, Breusch-Pagan-Godfrey heteroskedasticity test, and Ramsey RESET test. The outputs suggest that the model is acceptable since the null hypothesis is not rejected at the $5 \%$ significance level. ${ }^{2}$ Additionally, Figures 1 and 2 indicate that the CUSUM and CUSUM squares test substantiate the stability of the model. The next step is to interpret the short-run and long-run relationship among the variables, especially the demographic variables. Moreover, according to Table 4, all three null hypotheses of no cointegration among the variables are rejected. Thus, this paper has produced a convincing indication of cointegration. This conclusion is also in line with the cointegration output based on the first and second null hypotheses applied in Pesaran et al. (2001).

2 The null hypothesis of no autocorrelation at lag 2 in Table 3 is not rejected since the p-value is close to 0.05 , which is a borderline case (see Harel, 2009). 


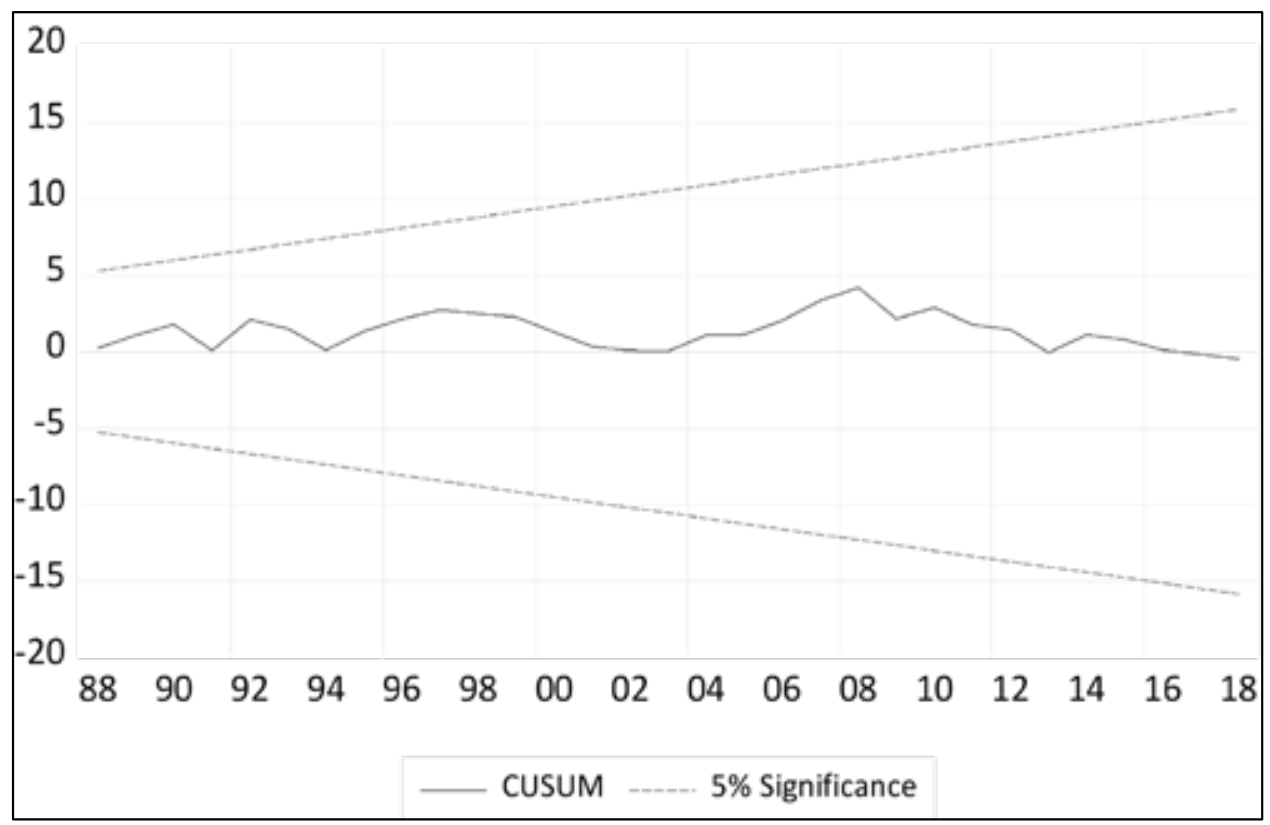

Figure 1. CUSUM

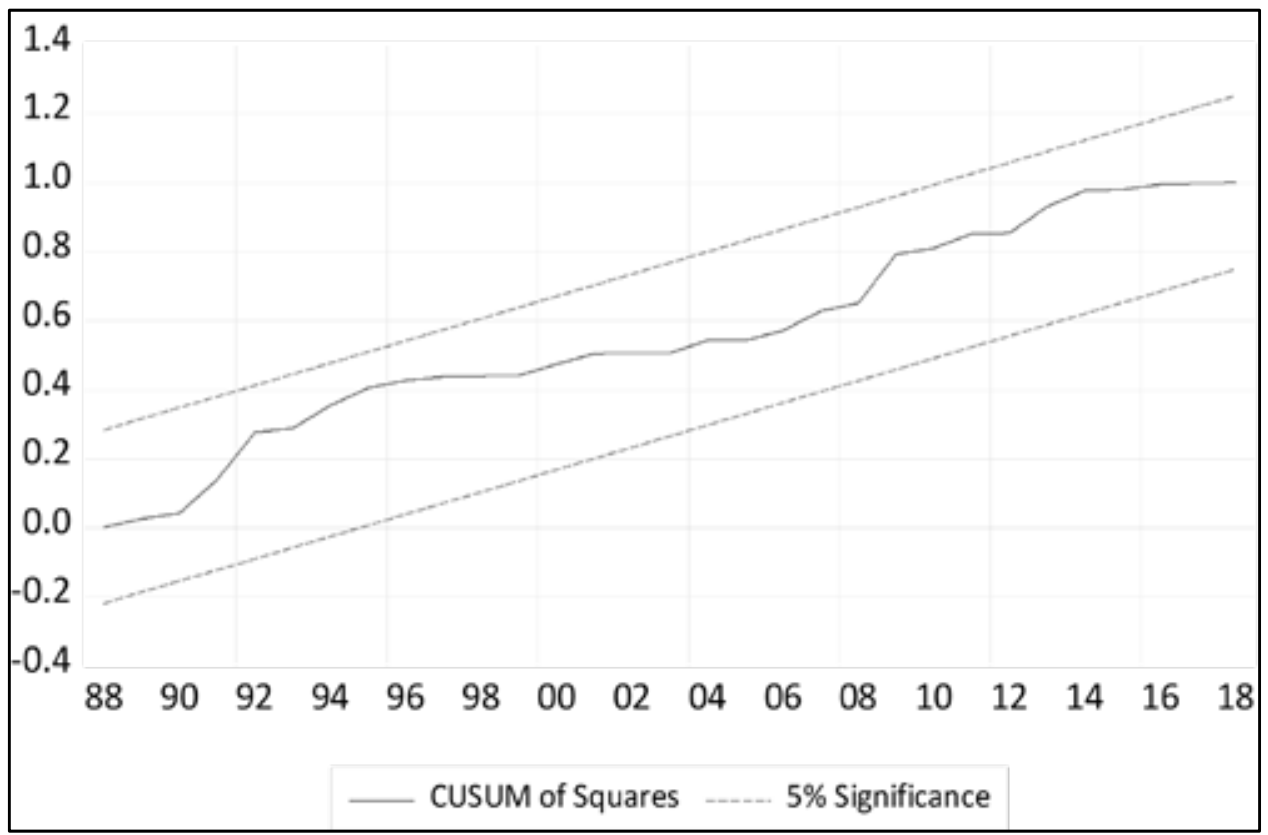

Figure 2. CUSUM squares 
Table 4. F-statistic and t-statistic for cointegration detection

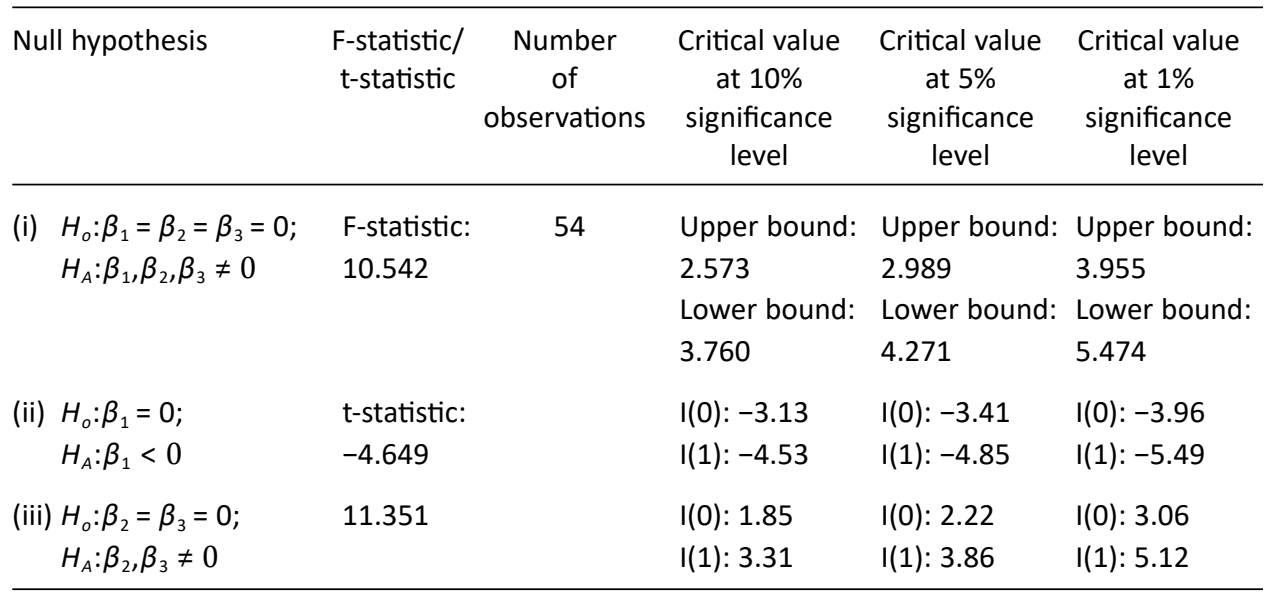

Note: The critical values of hypotheses (i), (ii) and (iii) are from Narayan (2005), Pesaran et al. (2011), and Sam et al. (2019), respectively. The values beside $I(0)$ and $I(1)$ are the critical values when the variables are purely I(0) and purely I(1), respectively.

Table 5 illustrates the short-run and long-run relationships. The short-run relationship is based on the restricted error correction model. In the short run, both demographic indicators are either absent or are not statistically significant. It is not surprising as the ageing factor will not have a quick implication on the economy. Surprisingly, the income level has a deflationary impact in the short run. Otherwise, the rising gross primary balance pushes the price level upward. As for the housing price and labour supply, the expected positive sign is found in some lags only, suggesting that the lag effect happens in the impact transmission process. More importantly, the lagged error correction term is negative and statistically significant. This statistically significant error term substantiates the cointegration relationship as when variables are cointegrated, any deviation from the long-term trend should be eliminated. Furthermore, the coefficient value of 0.1479 indicates that $14.79 \%$ of the deviations will be corrected the next year.

The demographic indicators are statistically significant in the long run. First, the increase in the old dependency ratio causes a deflationary effect on the price level. This deflationary effect is in line with the findings in the Japanese case from previous studies. Conversely, the young dependency rate will move the price level in the same direction, concurring with the empirical findings of Aksoy et al. (2019), Gajewski (2015), Juselius and Takats $(2015,2016)$, and Lindh and Malmberg $(1998,2000)$. The opposite effect of the old and young dependency rate is also found by Gajewski (2015) among the OECD countries. Bullard et al. (2012) suggested that the opposite price implication of the young and old dependency ratio is due to the different preferences in real interest rate, inflation and wage between old and young populations. The dependency of the young cohort on wages causes them to prefer low real interest rates, high inflation and high wage, whereas the old cohort will prefer low inflation. 
Table 5. Short-run and long-run coefficients of inflation equation

\begin{tabular}{|c|c|c|c|}
\hline Variable & Short-run coefficient & Variable & Long-run coefficient \\
\hline C & $8.6870(0.0000)^{* * *}$ & dold_dep & $-0.3227(0.0146)^{* *}$ \\
\hline Trend & $0.0049(0.0000)^{* * *}$ & dyoung_dep & $0.1135(0.0974)^{*}$ \\
\hline$\Delta / c p i_{t-1}$ & $0.2656(0.0153)^{* *}$ & $d l b m$ & $0.8352(0.0053)^{* * *}$ \\
\hline$\Delta / c p i_{t-2}$ & $-0.2773(0.0060)^{* * *}$ & Igdp_usd & $0.2727(0.0144)^{* *}$ \\
\hline$\Delta d o l d \_d e p$ & $0.0168(0.5129)$ & $g p b \_g d p$ & $-0.0122(0.1342)$ \\
\hline$\Delta / g d p \_u s d$ & $-0.0183(0.2220)$ & Ihpr & $1.1769(0.0007)^{* * *}$ \\
\hline$\Delta l g d p \_u s d_{t-1}$ & $-0.0574(0.0007)^{* * *}$ & IIf & $-6.2039(0.0001)^{* * *}$ \\
\hline$\Delta g p b \_g d p$ & $0.0037(0.0016)^{* * *}$ & & \\
\hline$\Delta / h p r$ & $-0.1615(0.0004)^{* * *}$ & & \\
\hline$\Delta / h p r_{t-1}$ & $0.1488(0.0127)^{* *}$ & & \\
\hline$\Delta / h p r_{t-2}$ & $-0.2709(0.0000)^{* * *}$ & & \\
\hline$\Delta l l f$ & $-0.8062(0.0088)^{* * *}$ & & \\
\hline$\Delta / l f_{t-1}$ & $1.3283(0.0006)^{* * *}$ & & \\
\hline$\Delta / l f_{t-2}$ & $0.1404(0.7121)$ & & \\
\hline$\Delta / l f_{t-3}$ & $1.2188(0.0005)^{* * *}$ & & \\
\hline$E C T_{t-1}$ & $-0.1479(0.0000)^{* * *}$ & & \\
\hline
\end{tabular}

Note: $C$ is the constant term, Trend is the trend component, and ECT denotes the error correction term. dold dep, dyoung_dep, and dllbm indicate the first difference of old_dep, young_dep, and $\mathrm{lbm}$, respectively. Value in parentheses is the $\mathrm{p}$-value of the variable. ${ }^{* * *}, * *$ and $*$ indicate significance level at $1 \%, 5 \%$ and $10 \%$, respectively.

Examining the other determinants shows that most variables behave as expected following the theory. Increases in $d l b m$, Igdp_usd, and Ihpr are associated with the price level positively. The positive relationship between the price level and the amount of money in the economy has been well-documented in the economic literature. A rise in income will lead to more demand for goods and services. Subsequently, the price level will rise, causing a positive coefficient sign of lgdp_usd. Similarly, a higher property price could increase the consumption tendency because of higher net worth. In the end, the price level will be pushed up.

If If increases, more labour availability reduces the labour supply constraint, which will cause the labour cost or the production cost to be lower, causing the reduction effect in overall prices. Nevertheless, a higher $g p b \_g d p$ has a statistically insignificant negative impact on the Japanese price level. This negative sign is also found in some estimations on Japanese data by Yoon et al. (2014). The statistically insignificant impact of gpb_gdp could occur because of the Ricardian Equivalent that is believed to happen in the Japanese economy (Bernanke, 2003). Moreover, the negative sign reflects the special situation in Japan where deflation happens even after the Japanese government implemented expansionary fiscal policies. Furthermore, the relatively small coefficient size of $g p b \_g d p$ compared with the demographic variables suggests a weaker role played by the fiscal stimulus plans in Japan. 


\section{Sensitivity Analysis and Transmission Channels}

\subsection{Sensitivity Analysis}

The sensitivity of the augmented ARDL is tested by inserting a time dummy to account for the potential impact from the 2009 fiscal stimulus package (DUM09) and excluding the young dependency ratio from the estimation. The fiscal stimulus package aims to avoid a shrinking economy due to the 2008 global financial crisis. Thus, there is a possibility that that policy could inflate the price level. Furthermore, excluding the young dependency ratio enables the study to observe the sensitivity of the results to the demographic measurements. SIC chooses ARDL $(2,1,0,2,1,3,4)$, and the model performs reasonably well at all diagnostic tests at a $5 \%$ significance level, as shown in Table 6 and Figures 3 and 4. Turning to the cointegration output, the augmented ARDL shows that cointegration exists in this sensitivity analysis since all null hypotheses of the cointegration test are rejected.

Table 6. Results of diagnostic tests for ARDL

\begin{tabular}{ll}
\hline Diagnostic test Result & \\
\hline Jacque-Bera test & $3.303(0.192)$ \\
Bruesch-Godfrey Serial correlation test (2 lag) & $5.317(0.070)$ \\
Bruesch-Godfrey Serial correlation test (4 lag) & $5.490(0.241)$ \\
Breusch-Pagan-Godfrey heteroskedasticity test & $29.063(0.1125)$ \\
Ramsey RESET F-statistic & $1.772(0.1928)$ \\
\hline
\end{tabular}

Note: The model specification of the ARDL is $(2,1,0,2,1,3,4)$. Value in parentheses is the p-value of the test.

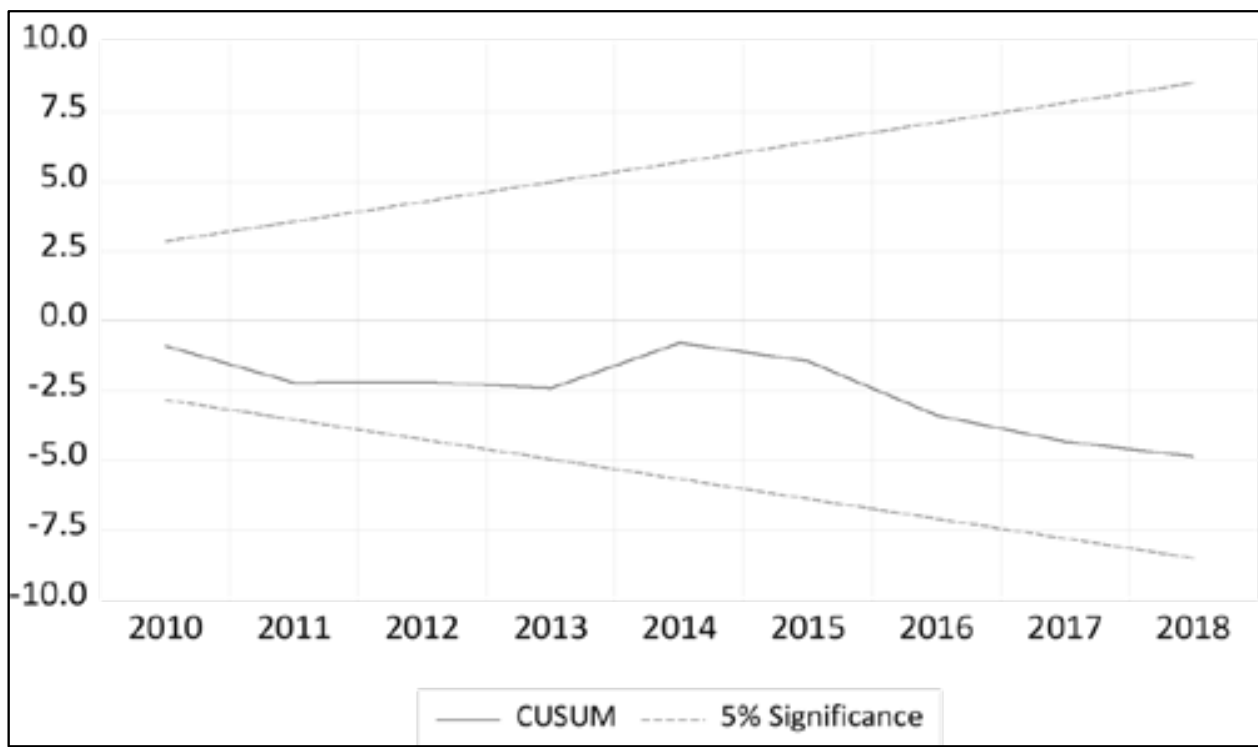

Figure 3. CUSUM (sensitivity analysis) 


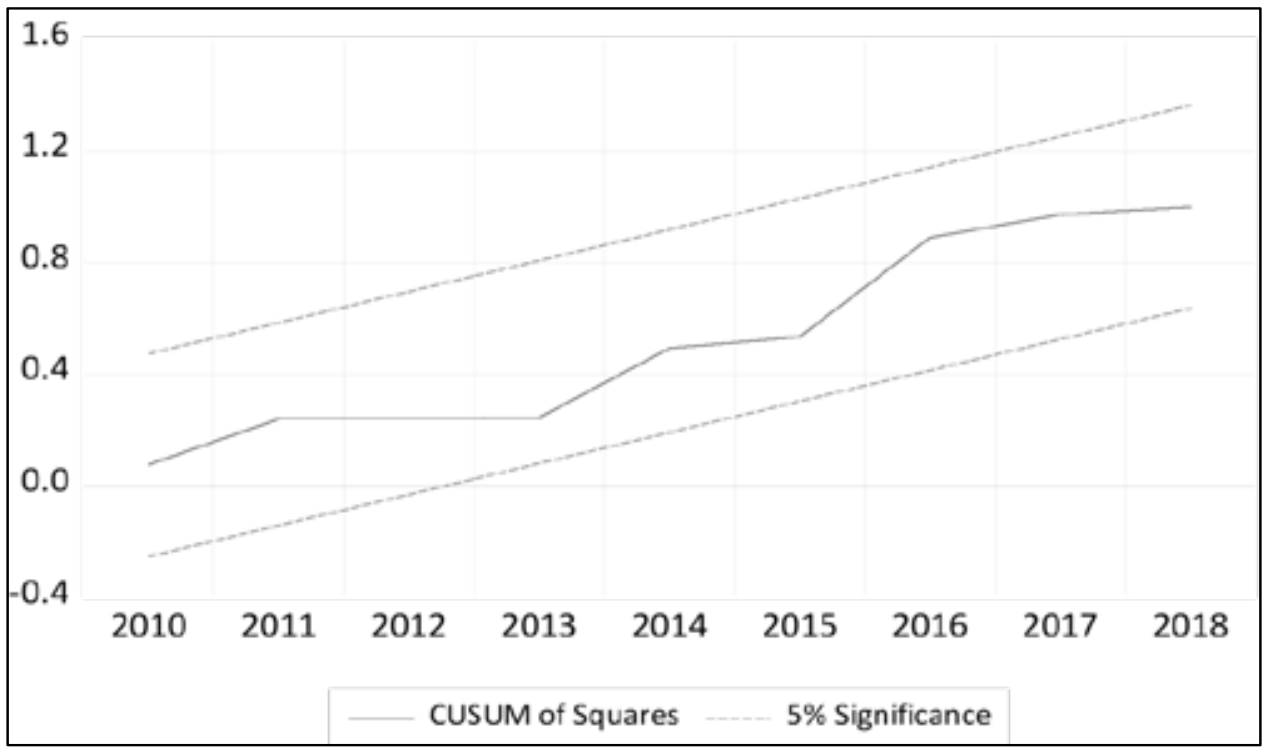

Figure 4. CUSUM square (sensitivity analysis)

Table 7. F-statistic and t-statistic for cointegration detection (sensitivity test)

\begin{tabular}{|c|c|c|c|c|c|}
\hline Null hypothesis & $\begin{array}{l}\text { F-statistic/ } \\
\text { t-statistic }\end{array}$ & $\begin{array}{c}\text { Number } \\
\text { of } \\
\text { observations }\end{array}$ & $\begin{array}{l}\text { Critical value } \\
\text { at } 10 \% \\
\text { significance } \\
\text { level }\end{array}$ & $\begin{array}{c}\text { Critical value } \\
\text { at } 5 \% \\
\text { significance } \\
\text { level }\end{array}$ & $\begin{array}{c}\text { Critical value } \\
\text { at } 1 \% \\
\text { significance } \\
\text { level }\end{array}$ \\
\hline (i) $\begin{array}{l}H_{o}: \beta_{1}=\beta_{2}=\beta_{3}=0 ; \\
H_{A}: \beta_{1}, \beta_{2}, \beta_{3} \neq 0\end{array}$ & $\begin{array}{l}\text { F-statistic: } \\
9.238\end{array}$ & 54 & $\begin{array}{l}\text { Upper bound: } \\
2.573 \\
\text { Lower bound: } \\
3.760\end{array}$ & $\begin{array}{l}\text { Upper bound: } \\
2.989 \\
\text { Lower bound: } \\
4.271\end{array}$ & $\begin{array}{l}\text { Upper bound: } \\
3.955 \\
\text { Lower bound: } \\
5.474\end{array}$ \\
\hline (ii) $\begin{array}{l}H_{o}: \beta_{1}=0 \\
H_{A}: \beta_{1}<0\end{array}$ & $\begin{array}{l}\text { t-statistic: } \\
-5.009\end{array}$ & N/A & $\begin{array}{l}\mathrm{I}(0):-3.13 \\
\mathrm{I}(1):-4.37\end{array}$ & $\begin{array}{l}\mathrm{I}(0):-3.41 \\
\mathrm{I}(1):-4.69\end{array}$ & $\begin{array}{l}I(0):-3.96 \\
I(1):-5.31\end{array}$ \\
\hline (iii) $\begin{array}{c}H_{o}: \beta_{2}=\beta_{3}=0 \\
H_{A}: \beta_{2}, \beta_{3} \neq 0\end{array}$ & 26.098 & N/A & $\begin{array}{l}\mathrm{I}(0): 1.90 \\
\mathrm{I}(1): 3.41\end{array}$ & $\begin{array}{l}I(0): 2.29 \\
I(1): 4.02\end{array}$ & $\begin{array}{l}I(0): 3.22 \\
I(1): 5.36\end{array}$ \\
\hline
\end{tabular}

Note: The critical values of hypotheses (i), (ii) and (iii) are from Narayan (2005), Pesaran et al. (2011), and Sam et al. (2019), respectively. The values beside $I(0)$ and $I(1)$ are the critical values when the variables are purely I(0) and purely I(1), respectively.

Moreover, the error correction term in Table 8 is statistically significant, valued at -0.1717 . This figure is close to the first estimation. It also means the cointegration relationship is again supported here. The short-term coefficients also show signs similar to those of the first estimation. As for the long-run coefficient, the significance of the old dependency ratio is found in the sensitivity analysis. Moreover, the other control variables have the same effect as indicated by the previous estimation. The only difference is that the fiscal variable turns statistically significant. 
Table 8. Short-run and long-run coefficients of inflation equation (sensitivity test)

\begin{tabular}{|c|c|c|c|}
\hline Variable & $\begin{array}{l}\text { Short-run coefficient } \\
\text { (p-value) }\end{array}$ & Variable & $\begin{array}{l}\text { Long-run coefficient } \\
\text { (p-value) }\end{array}$ \\
\hline C & $7.1545(0.0001)^{* * *}$ & dold_dep & $-0.3532(0.0043)^{* * *}$ \\
\hline Trend & $0.0053(0.0000)^{* * *}$ & $d l b m$ & $0.6899(0.0084)^{* * *}$ \\
\hline$\Delta / c p i_{t-1}$ & $0.3086(0.0024)^{* * *}$ & lgdp_usd & $0.2464(0.0159)^{* *}$ \\
\hline$\Delta d o l d \_d e p$ & $0.0214(0.4565)$ & $g p b \_g d p$ & $-0.0167(0.0179)^{* *}$ \\
\hline$\Delta / g d p \_u s d$ & $-0.0096(0.5612)$ & Ihpr & $1.0239(0.0002)^{* * *}$ \\
\hline$\Delta / g d p \_u s d_{t-1}$ & $-0.0624(0.0012)^{* * *}$ & $\| f$ & $-4.5208(0.0000)^{* * *}$ \\
\hline$\Delta g p b \_g d p$ & $0.0036(0.0015)^{* * *}$ & & \\
\hline$\Delta / h p r$ & $-0.1185(0.0109)^{* *}$ & & \\
\hline$\Delta / h p r_{t-1}$ & $0.2099(0.0008)^{* * *}$ & & \\
\hline$\Delta / h p r_{t-2}$ & $-0.2542(0.0000)^{* * *}$ & & \\
\hline$\Delta l l f$ & $-1.1513(0.0013)^{* * *}$ & & \\
\hline$\Delta / l f_{t-1}$ & $1.3491(0.0013)^{* * *}$ & & \\
\hline$\Delta / l f_{t-2}$ & $0.2084(0.6032)$ & & \\
\hline$\Delta / l f_{t-3}$ & $0.7763(0.0146)^{* *}$ & & \\
\hline DUM09 & $-0.0037(0.7945)$ & & \\
\hline$E C T_{t-1}$ & $-0.1717(0.0000)^{* * *}$ & & \\
\hline
\end{tabular}

Note: $C$ is the constant term, Trend is the trend component, and ECT denotes the error correction term. dold dep and $d \mathrm{lbm}$ indicate the first difference of old_dep and $\mathrm{lbm}$, respectively. Value in parentheses is the p-value of the variable. ${ }^{* * *}$ and ${ }^{* *}$ indicate significance level at $1 \%$ and $5 \%$, respectively.

\subsection{Transmission Channels}

Table 9 shows the pairwise Granger causality output. Only the results related to the direct Granger causality between ageing and price level and the transmission channels between both variables are presented to conserve space. A few conclusions can be drawn from this table. First, there is no direct bidirectional Granger causality between ageing in the price level in all observed lags. Second, ageing has affected broad money (at nine lags), fiscal balance (at six lags), and labour supply (at 15 lags). In other words, it takes a longer period for a change in ageing to affect the labour market.

Third, examining the pairwise Granger causality from the selected transmission variables indicates that only the real house price and the labour supply Granger causes the price level. The real house price Granger causes the price level in all lags except for lag 15, whereas the null hypothesis of no Granger causality is rejected in all lags for the case of labour supply. More importantly, one could conclude that ageing will affect the Japanese price level via its implication on the labour supply. Figure 5 summarises this conclusion in a chart. ${ }^{3}$

3 The impact of demographic variables on labour supply is tested as well using the ARDL method. The income level is included in the equation as a control variable. The estimation suggests that an increase in the old dependency ratio reduces the labour supply. The results are available upon request. 
Table 9. Pairwise Granger causality

\begin{tabular}{|c|c|c|c|c|c|}
\hline \multirow{2}{*}{ Null hypothesis } & \multicolumn{5}{|c|}{ F-statistics of Granger causality analysis ( $p$-value in parentheses) } \\
\hline & 3 lags & 6 lags & 9 lags & 12 lags & 15 lags \\
\hline $\begin{array}{l}\text { dold_dep does not } \\
\text { Granger cause Icpi }\end{array}$ & $\begin{array}{c}0.0492 \\
(0.9854)\end{array}$ & $\begin{array}{c}0.1575 \\
(0.9863)\end{array}$ & $\begin{array}{c}0.5627 \\
(0.8162)\end{array}$ & $\begin{array}{c}1.1469 \\
(0.3774)\end{array}$ & $\begin{array}{c}1.2886 \\
(0.3331)\end{array}$ \\
\hline $\begin{array}{l}\text { Icpi does not Granger } \\
\text { cause dold_dep }\end{array}$ & $\begin{array}{c}0.7875 \\
(0.5068)\end{array}$ & $\begin{array}{c}0.8477 \\
(0.5413)\end{array}$ & $\begin{array}{c}0.5755 \\
(0.8063)\end{array}$ & $\begin{array}{c}0.5343 \\
(0.8682)\end{array}$ & $\begin{array}{c}0.5530 \\
(0.8613)\end{array}$ \\
\hline $\begin{array}{l}\text { dold_dep does not } \\
\text { Granger cause } d l b m\end{array}$ & $\begin{array}{c}2.1901 \\
(0.1013)\end{array}$ & $\begin{array}{c}1.6524 \\
(0.1589)\end{array}$ & $\begin{array}{c}1.9078 \\
(0.0894)^{*}\end{array}$ & $\begin{array}{c}1.4003 \\
(0.2410)\end{array}$ & $\begin{array}{c}0.3440 \\
(0.9729)\end{array}$ \\
\hline $\begin{array}{l}\text { dold_dep does not } \\
\text { Granger cause lgdp_usd }\end{array}$ & $\begin{array}{c}1.0498 \\
(0.3792)\end{array}$ & $\begin{array}{c}1.1145 \\
(0.3717)\end{array}$ & $\begin{array}{c}1.4793 \\
(0.2007)\end{array}$ & $\begin{array}{c}1.4018 \\
(0.2403)\end{array}$ & $\begin{array}{c}0.8824 \\
(0.5969)\end{array}$ \\
\hline $\begin{array}{l}\text { dold_dep does not } \\
\text { Granger cause } g p b \_g d p\end{array}$ & $\begin{array}{c}1.7266 \\
(0.1741)\end{array}$ & $\begin{array}{c}1.9379 \\
(0.0988)\end{array}$ & $\begin{array}{c}1.4096 \\
(0.2281)\end{array}$ & $\begin{array}{c}1.6581 \\
(0.1498)\end{array}$ & $\begin{array}{c}1.7719 \\
(0.1617)\end{array}$ \\
\hline $\begin{array}{l}\text { dold_dep does not } \\
\text { Granger cause } \mathrm{Ihpr}\end{array}$ & $\begin{array}{c}0.4216 \\
(0.7384)\end{array}$ & $\begin{array}{c}0.6817 \\
(0.6653)\end{array}$ & $\begin{array}{c}0.4979 \\
(0.8641)\end{array}$ & $\begin{array}{c}0.4949 \\
(0.8950)\end{array}$ & $\begin{array}{c}0.6656 \\
(0.7743)\end{array}$ \\
\hline $\begin{array}{l}\text { dold_dep does not } \\
\text { Granger cause IIf }\end{array}$ & $\begin{array}{c}0.5223 \\
(0.6690)\end{array}$ & $\begin{array}{c}0.5313 \\
(0.7811)\end{array}$ & $\begin{array}{c}0.6641 \\
(0.7340)\end{array}$ & $\begin{array}{c}0.8929 \\
(0.5674)\end{array}$ & $\begin{array}{l}4.5586 \\
(0.0058)^{* * *}\end{array}$ \\
\hline $\begin{array}{l}\text { dlbm does not Granger } \\
\text { cause Icpi }\end{array}$ & $\begin{array}{c}0.9902 \\
(0.4054)\end{array}$ & $\begin{array}{c}0.7834 \\
(0.5881)\end{array}$ & $\begin{array}{c}0.6058 \\
(0.7821)\end{array}$ & $\begin{array}{c}0.4327 \\
(0.9316)\end{array}$ & $\begin{array}{c}1.7161 \\
(0.1756)\end{array}$ \\
\hline $\begin{array}{l}\text { Igdp_usd does not } \\
\text { Granger cause Icpi }\end{array}$ & $\begin{array}{c}1.7165 \\
(0.1761)\end{array}$ & $\begin{array}{c}1.1130 \\
(0.3725)\end{array}$ & $\begin{array}{c}0.6374 \\
(0.7562)\end{array}$ & $\begin{array}{c}1.0937 \\
(0.4130)\end{array}$ & $\begin{array}{c}0.8399 \\
(0.6308)\end{array}$ \\
\hline $\begin{array}{l}g p b \_g d p \text { does not } \\
\text { Granger cause Icpi }\end{array}$ & $\begin{array}{c}0.4908 \\
(0.6903)\end{array}$ & $\begin{array}{c}0.1823 \\
(0.9801)\end{array}$ & $\begin{array}{c}0.2452 \\
(0.9842)\end{array}$ & $\begin{array}{c}0.7359 \\
(0.7032)\end{array}$ & $\begin{array}{c}1.7872 \\
(0.1581)\end{array}$ \\
\hline $\begin{array}{l}\text { Ihpr does not Granger } \\
\text { cause Icpi }\end{array}$ & $\begin{array}{l}11.8887 \\
(0.0000)\end{array}$ & $\begin{array}{l}4.1915 \\
(0.0024)^{* * *}\end{array}$ & $\begin{array}{l}2.8486 \\
(0.0150)^{* *}\end{array}$ & $\begin{array}{l}2.0985 \\
(0.0661)^{*}\end{array}$ & $\begin{array}{c}1.9904 \\
(0.1177)\end{array}$ \\
\hline $\begin{array}{l}\text { Ilf does not Granger } \\
\text { cause Icpi }\end{array}$ & $\begin{array}{l}4.8445 \\
(0.0050)^{* * *}\end{array}$ & $\begin{array}{c}2.6077 \\
(0.0320)^{* *}\end{array}$ & $\begin{array}{c}0.2514 \\
(0.0280)^{* *}\end{array}$ & $\begin{array}{c}4.1086 \\
(0.0023)^{* *}\end{array}$ & $\begin{array}{c}2.1079 \\
(0.0996)^{*}\end{array}$ \\
\hline
\end{tabular}

Note: dold_dep and dlbm indicate the first difference of old_dep and $\mathrm{lbm}$, respectively. Value in parentheses is the $\mathrm{p}$-value of the variable. ${ }^{* * *},{ }^{* *}$ and $*$ indicate the significance level at $1 \%, 5 \%$ and $10 \%$, respectively.

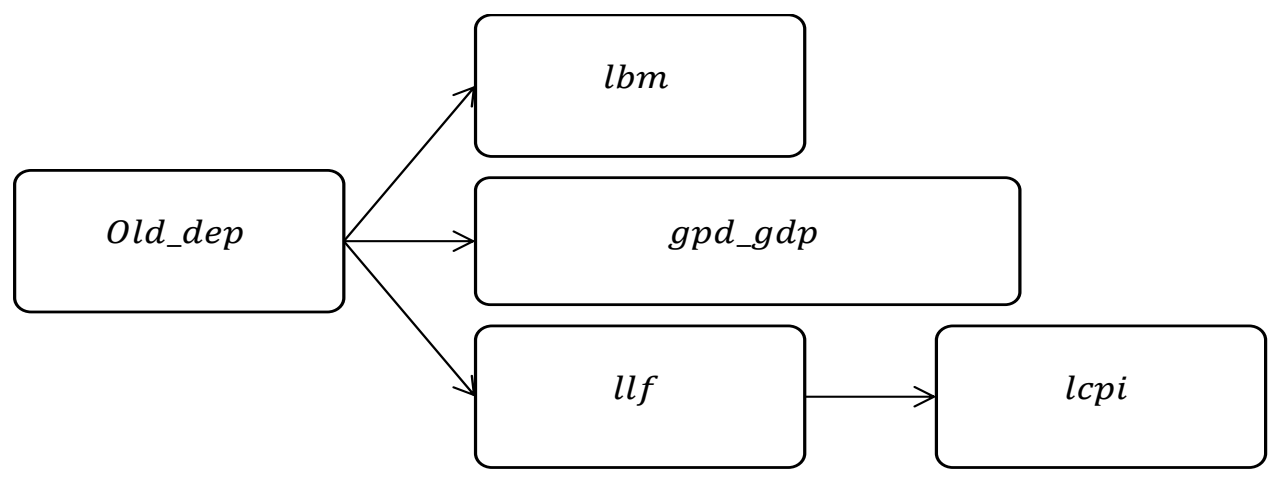

Figure 5. Linkage from dold_dep to Icpi 


\section{Conclusions}

Multiple economic stimulus plans have failed to arrest the deflationary phenomenon in Japan, leading to several attempts to link the phenomenon with the demographic impact of the old and young dependency ratios. This paper substantiates the claim that an increase in the old dependency ratio, an indicator of the ageing society, leads to deflation in Japan by using more recent data and a more rigorous augmented ARDL estimation. The young dependency rate exerts inflationary pressure. Additionally, ageing influences the price level negatively via its Granger causality with the labour supply. Furthermore, the demographic variables show a relatively strong influence on the price level than fiscal policy (i.e., fiscal budget in this paper).

A significant policy implication of this paper is that if a structural change in the demographic influences a price level negatively, the fiscal stimulus implemented by the Japanese government to prompt a short-term surge in demand might not be effective to reverse the price trend. To reduce the negative implication of ageing on the price level, a more effective demographic policy could be drawn to attract young migrants with stronger purchasing power. The migrants will also increase the labour force. Moreover, a labour policy that facilitates the aged citizens to participate in the labour market is needed to minimise the shrinking effect of ageing on the labour force supply.

\section{References}

Aksoy, Y., Basso, H.S., Smith, R.P., \& Grasl, T. (2019). Demographic structure and macroeconomic trends. American Economic Journal: Macroeconomics, 11(1), 193-222. https://doi.org/ 10.1257/mac.20170114

Anderson, D., Botman, D., \& Hunt, B. (2014). Is Japan's population aging deflationary? (IMF working paper WP/14/139). https://www.imf.org/external/pubs/ft/wp/2014/wp14139.pdf

Bernanke, B. (2003). Some thoughts on monetary policy in Japan. https://www.bis.org/review/ r030606d.pdf

Bobeica, E., Nickel, C., Lis, E., \& Sun, Y. (2017). Demographics and inflation (ECB working paper No. 2006). https://doi.org/10.2866/339353

Broniatowska, P. (2019). Population aging and inflation. Population Ageing, 12, 179-193. https:// doi.org/10.1007/s12062-017-9209-z

Bullard, J., Garriga, C., \& Waller, C.J. (2012). Demographics, redistribution, and optimal inflation (Federal Reserve Bank of St. Louis Review, November/December 2012), 419-439. https:// files.stlouisfed.org/files/htdocs/publications/review/12/11/Bullard.pdf

De Albuquerque, P.C.A.M., Caiado, J., \& Pereira, A. (2020). Population aging and inflation: Evidence from panel cointegration. Journal of Applied Economics, 23(1), 469-484. https:// doi.org/10.1080/15140326.2020.1795518

Enders, W. (2015). Applied Econometric Time Series (4th ed.). Wiley.

Fujita, S., \& Fujiwara, I. (2016). Declining trend in the real interest rate and inflation: The role of aging (Federal Reserve Bank of Philadelphia working paper No. 16-29). https://www. philadelphiafed.org/the-economy/macroeconomics/declining-trends-in-the-real-interestrate-and-inflation

Gajewski, P. (2015). Is ageing deflationary? Some evidence from OECD countries. Applied Economics Letters, 22(11), 916-919. https://doi.org/10.1080/13504851.2014.987911

Goh, S.K., McNown, R., \& Wong, K.N. (2020). Macroeconomic implications of population aging: Evidence from Japan. Journal of Asian Economics, 68, Article 101198. https://doi. org/10.1016/j.asieco.2020.101198 
Han, G. (2019). Demographic changes and inflation dynamics (HKIMR working paper No. 02/2019). https://doi.org/10.2139/ssrn.3315033

Harel, O. (2009). The estimation of $R^{2}$ and adjusted $R^{2}$ in the incomplete data sets using multiple imputation. Journal of Applied Statistics, 36(10), 1109-1118. https://doi.org/10.1080/ 02664760802553000

Juselius, M., \& Takats, E. (2015). Can demography affect inflation and monetary policy? (BIS working papers No. 485). https://www.bis.org/publ/work485.htm

Juselius, M., \& Takats, E. (2016). The age-structure-inflation puzzle (Bank of Finland research discussion papers No. 4/2016). https://nbn-resolving.de/urn:NBN:fi:bof-201604051074

Katagiri, M. (2012). Economic consequences of population aging in Japan: Effects through changes in demand structure (IMES discussion paper No. 2012-E-3). http://www.imes.boj.or.jp/ research/papers/english/12-E-03.pdf

Katagiri, M., Konishi, H., \& Ueda, K. (2020). Aging and deflation from a fiscal perspective. Journal of Monetary Economics, 111, 1-15. https://doi.org/10.1016/j.jmoneco.2019.01.018

Levin, E., Montagnoli, A., \& Wright, R.E. (2008). Demographic change and the housing market: Evidence from a comparison of Scotland and England. Urban Studies, 46(1), 27-43. https:// www.jstor.org/stable/43198459

Lindh, T., \& Malmberg, B. (1998). Age structure and inflation - a Wisksellian interpretation of the OECD data. Journal of Economic Behavior \& Organization, 36(1), 19-37. https://doi. org/10.1016/S0167-2681(98)00068-7

Lindh, T., \& Malmberg, B. (2000). Can age structure forecast inflation trend? Journal of Economics and Business, 52(1-2), 31-49. https://doi.org/10.1016/S0148-6195(99)00026-0

Liu, Y., \& Westelius, N. (2016). The impact of demographics on productivity and inflation in Japan (IMF working paper WP/16/237). https://www.imf.org/external/pubs/ft/wp/2016/wp16237. pdf

McNown, R., Sam, C.Y., \& Goh, S.K. (2018). Bootstrapping the autoregressive distributed lag test for cointegration. Applied Economics, 50(13), 1509-1521. https://doi.org/10.1080/00036846. 2017.1366643

National Institute of Population and Social Security Research (2017). Population Projections for Japan (2016-2026): Summary. https://www.ipss.go.jp/pp-zenkoku/e/zenkoku_e2017/ pp_zenkoku2017e_gaiyou.html

Narayan, P.K. (2005). The saving and investment nexus for China: Evidence from cointegration tests. Applied Economics, 37(17), 1979-1990. https://doi.org/10.1080/00036840500278103

Nishimura, K.G., \& Takats, E. (2012). Ageing, property prices and money demand (BIS Working Paper No. 385). https://www.bis.org/publ/work385.htm

Pesaran, M.H., Shin, Y., \& Smith, R.J. (2001). Bound testing approach to the analysis of level relationship. Journal of Applied Econometrics, 16(3), 289-326. https://doi.org/10.1002/ jae.616

Sam, C.Y., McNown, R., \& Goh, S.K. (2019). An augmented autoregressive distributed lag bound test for cointegration. Economic Modelling, 80, 130-141. https://doi.org/10.1016/j. econmod.2018.11.001

Societe Generale. (2016). Population aging: Risk of deflation or inflation? (ECONOTE No. 35). https://www.societegenerale.com/sites/default/files/Econote-n38-Italy-companiesdifficulties-are-hampering-investment-and-growth-potential.pdf

Yoon, J.-W., Kim, J., \& Lee, J. (2014). Impact of demographic changes on inflation and the macroeconomy (IMF working paper WP/14/210). https://www.imf.org/external/pubs/ft/wp/2014/ wp14210.pdf 
